\title{
A Modifled Method for the Rapid Analysis of Long-Chain Alkanes and Neophytadiene from Tobacco*
}

\author{
by R. F. Severson, K. L. McDuffie, R. F. Arrendale and O. T. Chortyk \\ Tobacco and Health Laboratory, Science and Education Administration / Agricultural Research, \\ United States Department of Agriculture, Athens, Georgia, U.S.A.
}

\section{INTRODUCTION}

Among the major classes of compounds on the surface of the tobacco leaf are the aliphatic hydrocarbons, which consist primarily of $\mathrm{C}_{25}-\mathrm{C}_{36}$ chain length compounds. Mold et al. (1) established that they consisted of a homologous series of normal ( $n$ ), iso (i, 2-methyl, and anteiso (a, 3-methyl) compounds. These findings were later confirmed by gas chromatography - mass spectrometry (GCMS) studies (2). Studies by Jenkins et al. $(3,4)$, Chortyk et al. (2), and Severson et al. (5) showed that the hydrocarbons are essentially transferred unchanged to smoke. Ivanov and Ognyanov (6) reported that the paraffinic hydrocarbons have a negative effect on smoke flavor and according to Davis (7) they are probably not related to leaf quality.

However, recent observations in our laboratory indicate that the hydrocarbons may be important leaf constituents. During lipid analyses of insect resistant and non-resistant tobaccos, we found that all analyzed tobaccos had essentially identical sterol and fatty acid distributions. However, each tobacco appeared to have its own characteristic hydrocarbon distribution. For example, several differences in distribution and in the ratios of normal to branched-chain alkanes were observed. For the fluecured NC 2326 tobacco, we also observed that different crop years, leaf position, and fertilization practices had little, if any, effects on hydrocarbon distributions. Thus, hydrocarbon distribution may be indicative of a tobacco's genetic badkground and hydrocarbons could be used as chemotaxonomic markers in tobacco breeding work. Consequently, it was important that varietal differences in hydrocarbon distribution should be further investigated. However, such a study would require the analyses of numerous tobacco samples. Examination of existing methods of analyses indicated that they were too time-consuming to allow the examination of numerous samples and that new methodology needed to be developed.

Traditionally, hydrocarbons have been extracted from ground tobacco by hexane in a Soxhlet apparatus. After

\footnotetext{
2 Received: 2nd April 1980 - accepted: 18th November 1980.
}

separation from interfering hexane-solubles by silicic acid (SA) column chromatography, they have been quantitated by conventional gas chromatography (GC) methods $(2,7,8,9)$. The lengthy Soxhlet extraction time (3-24 h) and the number of manipulations required for assembly and disassembly of the apparatus were obviously undesirable for daily analyses of many samples.

In our previous hydrocarbon analyses, the GC step involved the use of a packed Dexsil $300 \mathrm{GC}$ column and required a long temperature program to separate the hydrocarbons (Figure 1). Also, this system partially resolved the normal from the methyl-branched isomers, but failed to yield any resolution of the iso and anteiso isomers. Consequently, this GC method also required improvements.

In this report, we describe two major modifications of the traditional hydrocarbon-neophytadiene analysis method: an ultrasonic vibration-extraction procedure using methylene chloride and analysis of the hydrocarbon-neophytadiene isolate by glass capillary GC. Both improvements greatly decreased analysis time, and the use of capillary GC permitted the separation and the quantitation of all of the hydrocarbon isomers.

Flgure 1. Chromatogram of tobacco hydrocarbon Isolate on a $4.6 \mathrm{~cm} \times 6 \mathrm{~mm}$ stainless steel column packed with Dexsil 300 GC on 80/100 mesh Chromosorb W/AW (100$325^{\circ} \mathrm{C}$ at $4^{\circ} / \mathrm{min}$ ).

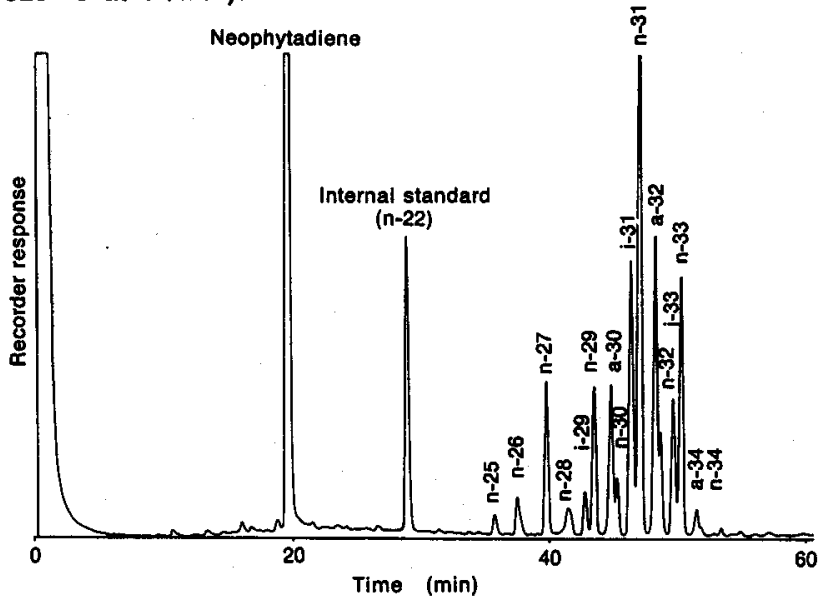




\section{EXPERIMENTAL}

\section{Materials}

All solvents used were Burdick and Jackson" "distilledin-glass" grade and were redistilled in glass before use. The hydrocarbon standards were obtained from Analabs, Inc. and were checked for purity before use.

\section{Tobacco Preparation and Dry Weight Determination}

The NC 2326 tobacco used in this study was grown and cured, under conditions normally used for flue-cured tobacco, at the Tobacco Research Laboratory, Oxford, North Carolina, in 1978. The tobacco was ground to 32 mesh in a Wiley mill. For moisture determination, about $500 \mathrm{mg}$ of ground tobacco was heated for $3 \mathrm{~h}$ at $95 \pm 0.05^{\circ} \mathrm{C}$ in a vented oven.

\section{Metbylene Chloride-Ultrasonic Vibration Extraction}

About $0.5 \mathrm{~g}$ of tobacco was weighed into a $500 \mathrm{ml}$ screwtop Erlenmeyer flask. To the flask were added $200 \mathrm{ml}$ of $\mathrm{CH}_{2} \mathrm{Cl}_{2}$ and $1 \mathrm{ml}$ of the internal standard solution [3-methyltricosane $\left(a-C_{34}\right), 0.08 \mathrm{mg} / \mathrm{ml}$ in hexane]. The flask was placed in an ultrasonic vibration bath at room temperature for $15 \mathrm{~min}$. The mixture was filtered through folded filter paper (Reeve Angel 802) into a $500 \mathrm{ml}$ round-bottom flask. The flask, filter, and funnel were rinsed with $50 \mathrm{ml}$ of hexane, and the resulting solution was reduced on a rotary evaporator at $30^{\circ} \mathrm{C}$ and under house vacuum $(\approx 20 \mathrm{~mm} \mathrm{Hg}$ ) to a volume of about $2 \mathrm{ml}$. The residue was quantitatively transferred to a $10 \mathrm{ml}$ volumetric flask with hexane (stock solution).

\section{Hexane-Soxblet Extraction}

About $2 \mathrm{~g}$ of tobacco was placed into a paper extraction thimble $(25 \times 80 \mathrm{~mm})$ and covered with a glass wool plug. Four milliliters of the internal standard solution $\left(a-\mathrm{C}_{2}, 0.08 \mathrm{mg} / \mathrm{ml}\right)$ and $200 \mathrm{ml}$ of hexane were placed in a boiling flask and the tobacco was extracted for $8 \mathrm{~h}$. The solvent was removed as above and the residue was quantitatively transferred to a $10 \mathrm{ml}$ volumetric flask (stock solution).

\section{Silicic Acid Chromatography}

A Fisher and Porter $150 \mathrm{~mm} \times 9 \mathrm{~mm}$ inside diameter chromatographic column equipped with a sintered glass disc, tapered stockcock, and a $250 \mathrm{ml}$ globe-shaped reservoir was slurry-packed with $2.5 \mathrm{~g}$ of "Unisil" silicic acid (Clarkson Chemical Co., Williamsport, Pennsylvania, $100 / 120$ mesh, activated at $150^{\circ} \mathrm{C}$ for $2 \mathrm{~h}$ ) in hexane. An aliquot of the stodk solution $(5 \mathrm{ml}$ from the ultrasonic vibration extraction or $\mathbf{2} \mathrm{ml}$ from the Soxhlet extraction) was placed on top of the column and the column was eluted with $50 \mathrm{ml}$ of hexane into a $250 \mathrm{ml}$ round-bottom flask. The column was operated under 3-5 p.s.i.** ni-

\footnotetext{
- Refereace to a company at product name does nos imply approyal or
} recommendation by the United States Department of Agriculture. trogen pressure. The hexane fraction was concentrated on a rotary evaporator and the residue was transferred with hexane to a tapered test tube. The hexane was removed under nitrogen and the residue was redissolved in $100 \mu \mathrm{l}$ of isooctane to yield the hydrocarbon-neophytadiene isolate.

\section{Glass Capillary Gas Cbromatography}

Half $(50 \mu \mathrm{l})$ of the above hydrocarbon isolate was placed in a microautoinjector vial, capped, and a $1 \mu \mathrm{l}$ portion was analyzed in a Hewlett-Packard 5830 gas dhromatograph, equipped with a Model $7671 \mathrm{~A}$ automatic sampler. Glass capillary GC separation was conducted on a $30 \mathrm{~m} \times 0.25 \mathrm{~mm}$ inside diameter dynamically coated SE-54 glass capillary column (10) (linear flow velocity, $28 \mathrm{~cm} / \mathrm{s}$ helium; split flow, $100 \mathrm{ml} / \mathrm{min}$; oven temperature program, $160-280^{\circ} \mathrm{C}$ at $4 \% \mathrm{~min}$, injection port temperature, $300^{\circ} \mathrm{C}$; flame ionization detector temperature, $325^{\circ} \mathrm{C}$; helium make-up, $30 \mathrm{ml} / \mathrm{min}$; hydrogen, $30 \mathrm{ml} /$ $\mathrm{min}$; air, $250 \mathrm{ml} / \mathrm{min}$ ). The gas chromatograph was modified for use with glass capillary columns as previously described (11).

\section{Component Identification and Quantitation}

Neophytadiene and hydrocarbons were identified by conventional GC-MS methods, using a Dexsil 300 column, as previously reported (2). Identifications for the glass capillary GC separations were based on the retention times of the commercially available straight-chain hydrocarbons and the elution orders of the $n-, i-$, and $a$-isomers of $\mathrm{C}_{\mathrm{zi}}$. Components were quantitated using the internal standard data reduction method supplied with the Hewlett-Packard $5830 \mathrm{GC}$ system. Based on the fact that the $n$-, $i$-, and a-isomers of $C_{24}$ yielded identical gas chromatographic responses, the branched isomers were assumed to yield GC responses identical to those of the commercially available straight-chain components. Neophy tadiene was assumed to yield a GC response identical to phytane. Yields of neophytadiene and hydrocarbons were based on the amount of internal standard added to the sample before extraction.

\section{RESULTS AND DISCUSSION}

In order to obtain more information on the level of each hydrocarbon isomer, we investigated glass capillary GC separation techniques. However, the commercial capillary injection system purchased with the gas chromatograph failed to yield reproducible and linear response data with standards. For hydrocarbons above $C_{z s}$ the response dropped off dramatically and was very erratic and the system was not satisfactory for obtaining quantitative data. Therefore, we modified the standard on-column injection port as shown in Figure 2. A glass insert prepared from standard $6.4 \mathrm{~mm} \times 2 \mathrm{~mm}$ inside diameter

\footnotetext{
** pound per square ind
} 
Figure 2. Modliled Injector syetem for glase capillary gas chromatography analyels.

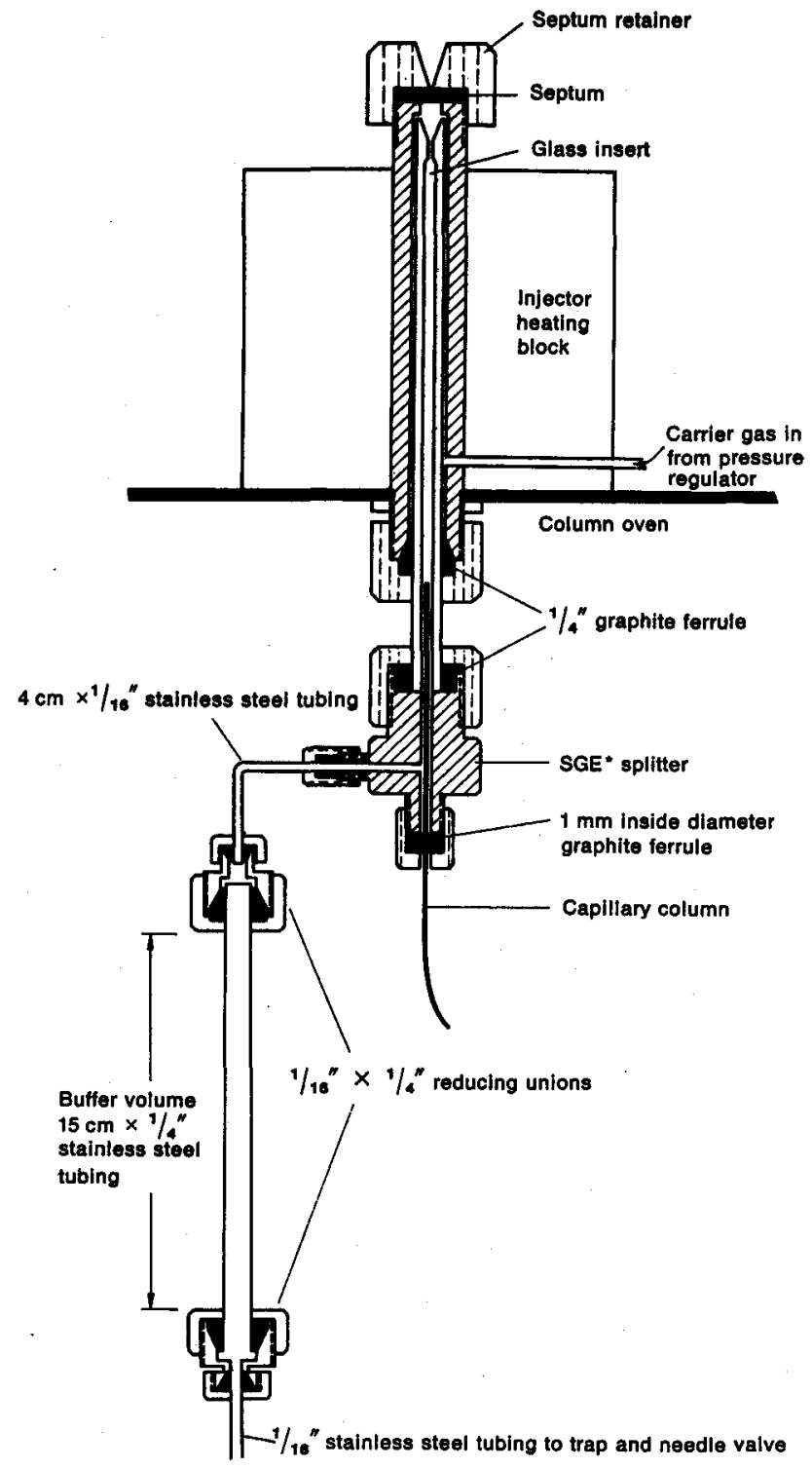

- Sclentiflc Glass Engineerlng Pty., Ltd., Melbourne, Australia.

Pyrex glass tubing was secured to the end of the port with graphite ferrules. To the end of the tube we attached a commercially available splitter (Scientific Glass Engineering Pty., Ltd., Melbourne, Australia). The end of the capillary column was placed up into the insert, thus providing for an all glass system. A buffer volume was required to obtain linear response. Analyses were performed in the split mode of operation. A split flow of $100 \mathrm{ml} / \mathrm{min}$ was found to be optimum for linear split. The complete modification method is detailed elsewhere (11). Using this modification, we found that a $30 \mathrm{~m} \mathrm{SE-54}$ capillary column not only resolved the $n-, i-$, and $a$-isomers (Figure 3), but also reduced GC analysis time by about 50\% compared to conventional, packed column GC.

Table 1 lists response reproducibility data obtained on the modified capillary system for a standard hydrocarbon mixture. As desired, we obtained essentially linear response from $C_{20}$ to $C_{94}$, with relative standard deviations of less than 2\%. Data on triplicate GC analyses of isolated tobacco hydrocarbons, using autoinjection, are given in Table 2. The data show that an acceptable capillary system had been constructed.

Since it is well documented that hydrocarbons are on the surface of the leaf $(7,12,13)$, it appeared that an ultrasonic vibration solvent extraction of ground tobacco would be satisfactory to remove the hydrocarbons. Based on the addition of 3-methyltricosane to the tobacco samples, we found that 15 min ultrasonic vibration extraction of $0.5 \mathrm{~g}$ of ground tobacco with $200 \mathrm{ml}$ of methylene chloride resulted in quantitative recovery of the tobacco hydrocarbons. Other solvent to tobacco ratios and extraction times were not investigated. Consequent$1 y$, the scheme in Figure 4 was used to isolate the hydrocarbons and neophytadiene and obtain quantitative data. Capillary GC was used to compare extraction efficiencies of the standard Soxhlet and the ultrasonic vibration extraction methods. The data on reproducibilities for the methylene chloride ultrasonic vibration extraction method and for the traditional Soxhlet extraction procedure are given in Table 3 . In order to reduce the variability of the data due to GC analysis (see Table 2), each set of data in Table 3 is the average of two GC determinations per replicate sample. Both methods resulted in the isolation of hydrocarbon fractions with essentially identical levels of individual and total hydrocarbons. Because of their low levels in leaf, $\mathrm{C}_{26}$ and $\mathrm{C}_{34}$ hydrocarbons yielded data that showed high relative standard deviations.

Since the ultrasonic vibration extraction step can be performed in less than half an hour compared to $8 \mathrm{~h}$ Soxhlet extractions, a large number of samples can be simultaneously extracted in one working day. Analysis time for

Table 2. Reproduclblilty of glass caplliary gas chromatography analyses.

\begin{tabular}{l|c|c|c|c}
\hline & \multicolumn{4}{|c}{ Leaf percentage $\times 100^{*}$} \\
\cline { 2 - 5 } Component & run 1 & run 2 & run 3 & $\begin{array}{c}\text { Average } \\
\text { I percent } \\
\text { rel. S.D.** }\end{array}$ \\
\hline$n-C_{28}$ & 0.14 & 0.14 & 0.14 & $0.14 \pm 0.0$ \\
$n-C_{27}$ & 0.99 & 1.01 & 0.99 & $1.00 \pm 1.2$ \\
$i-C_{30}$ & 0.08 & 0.08 & 0.08 & $0.08 \pm 0.0$ \\
$a-C_{30}$ & 1.00 & 1.08 & 1.06 & $1.05 \pm 4.0$ \\
$n-C_{30}$ & 0.41 & 0.44 & 0.44 & $0.43 \pm 4.0$ \\
$i-C_{31}$ & 1.54 & 1.72 & 1.60 & $1.62 \pm 5.7$ \\
$a-C_{31}$ & 0.28 & 0.31 & 0.30 & $0.30 \pm 5.1$ \\
$n-C_{31}$ & 3.66 & 4.09 & 4.03 & $3.93 \pm 5.9$ \\
$i-C_{32}$ & 0.13 & 0.15 & 0.14 & $0.14 \pm 7.1$ \\
$a-C_{32}$ & 1.47 & 1.68 & 1.62 & $1.59 \pm 6.8$ \\
$n-C_{32}$ & 0.63 & 0.72 & 0.68 & $0.68 \pm 6.7$ \\
Total $_{25}-C_{34}$ & 14.5 & 15.6 & 15.3 & $15.13 \pm 3.8$ \\
Neophytadiene & 13.5 & 13.6 & 13.6 & $13.57 \pm 0.4$ \\
\hline
\end{tabular}

- Calculated assuming unitary detector response.

* Relative standard deviation = S.D./mean $\times 100$. 
Table 1. GC peak Identifications and response data on hydrocarbons.

\begin{tabular}{|c|c|c|}
\hline Peak No. & Compound & $\begin{array}{l}\text { Response factor }(K)^{*} \\
\pm \text { percent rel. S.D. * }\end{array}$ \\
\hline & Phytane & $0.99 \pm 1.1$ \\
\hline 1 & Neophytadiene & \\
\hline \multirow[t]{2}{*}{2} & $a-C_{24}$ & 1.00 \\
\hline & $n-C_{24}$ & $0.99 \pm 0.4$ \\
\hline 3 & $n-C_{25}$ & $0.99 \pm 0.4$ \\
\hline 4 & $n-C_{28}$ & $0.99 \pm 0.6$ \\
\hline 5 & $a-C_{27}$ & \\
\hline 6 & $n-C_{27}$ & $0.99 \pm 0.4$ \\
\hline 7 & $i-C_{28}$ & \\
\hline 8 & $a-c_{28}$ & \\
\hline 9 & $n-C_{20}$ & $0.99 \pm 0.8$ \\
\hline 10 & $i-C_{29}$ & \\
\hline 11 & $a-C_{20}$ & \\
\hline 12 & $n-C_{29}$ & \\
\hline 13 & $i-\mathrm{C}_{30}$ & \\
\hline 14 & $a-C_{30}$ & \\
\hline 15 & $n-C_{30}$ & $0.99 \pm 1.7$ \\
\hline 16 & $i-\mathrm{C}_{31}$ & \\
\hline 17 & $a-C_{31}$ & \\
\hline 18 & $n-C_{31}$ & $1.05 \pm 1.2$ \\
\hline 19 & $i-\mathrm{C}_{32}$ & \\
\hline 20 & $a-C_{32}$ & \\
\hline 21 & $n-C_{32}$ & $1.04 \pm 1.7$ \\
\hline 22 & $i-\mathrm{C}_{33}$ & \\
\hline 23 & $a-C_{33}$ & \\
\hline 24 & $n-C_{33}$ & \\
\hline 25 & $\mathrm{I}-\mathrm{C}_{34}$ & \\
\hline 26 & $a-C_{34}$ & \\
\hline 27 & $n-C_{34}$ & $1.05 \pm 1.3$ \\
\hline 28 & $i-\mathrm{C}_{38}$ & \\
\hline 29 & $n-C_{35}$ & \\
\hline 30 & $a-C_{36}$ & \\
\hline 31 & $n-C_{36}$ & \\
\hline
\end{tabular}

* $K=$ (weight compound / area compound) / (weight standard / area standard).

* Relative standard devlation = S.D./mean $\times 100$.
Figure 4. Hydrocarbon analysis method.

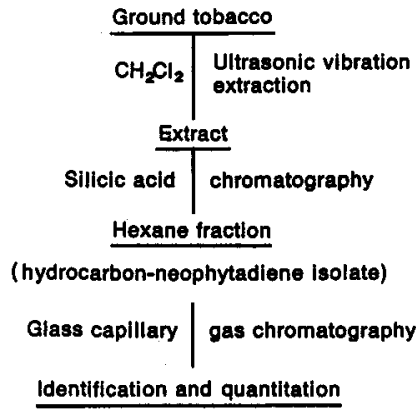

Figure 3. Caplliary chromatogram of tobacco hydrocarbon Isolate on a $0.25 \mathrm{~mm} \times 30 \mathrm{~mm}$ SE-54 wall-coated open tubular column $\left(160-280^{\circ} \mathrm{C}\right.$ at $\left.4^{\circ} / \mathrm{min}\right)$. (See Table 1 for peak identifications.)

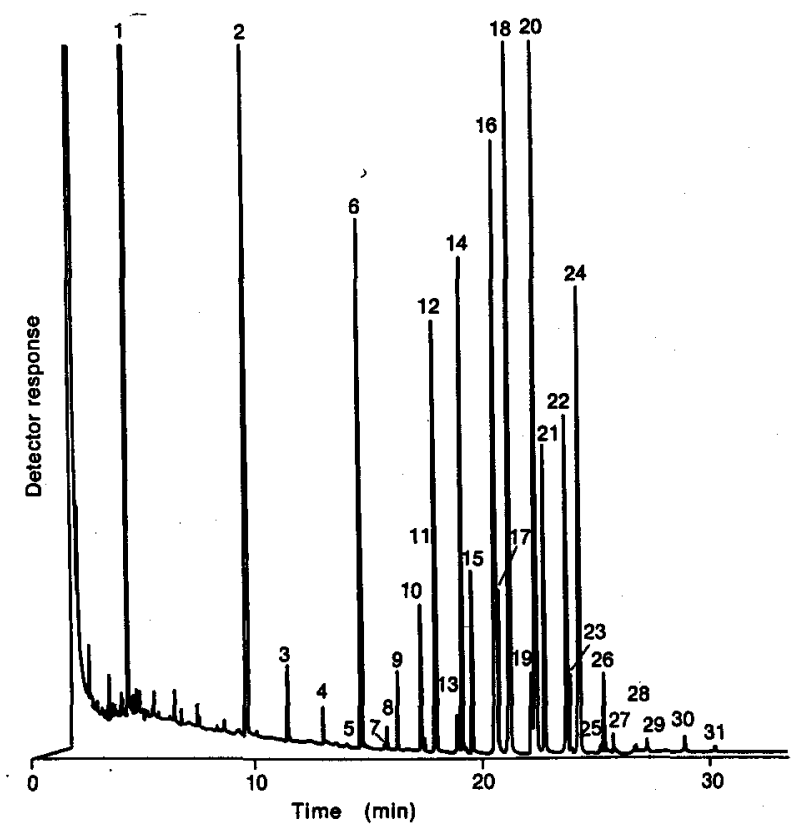


Table 3. Comparlson of $\mathrm{CH}_{2} \mathrm{Cl}_{2}$ ultrasonic vlbration and hexane - Soxhlet extractlon methods.

\begin{tabular}{|c|c|c|c|c|c|c|c|c|}
\hline \multirow{2}{*}{ Compound } & \multicolumn{4}{|c|}{$\mathrm{CH}_{2} \mathrm{Cl}_{2}$ - ultrasonic vibration } & \multicolumn{4}{|c|}{ Hexane-Soxhlet } \\
\hline & replicate 1 & replicate 2 & replicate 3 & $\begin{array}{c}\text { average } \\
\pm \text { rel. S.D. }\end{array}$ & replicate 1 & replicate 2 & replicate 3 & $\begin{array}{l}\text { average } \\
\pm \text { rel. S.D. }\end{array}$ \\
\hline \multicolumn{9}{|c|}{ Percentage distribution" } \\
\hline $\mathrm{C}_{28}^{* *}$ & 0.78 & 0.78 & 0.83 & $0.80 \pm 3.6$ & 0.75 & 0.70 & 0.71 & $0.72 \pm 3.7$ \\
\hline $\mathrm{C}_{26}$ & 0.39 & 0.38 & 0.56 & $0.44 \pm 22.8$ & 0.45 & 0.36 & 0.33 & $0.36 \pm 16.4$ \\
\hline $\mathrm{C}_{27}$ & 5.66 & 5.66 & 5.68 & $5.67 \pm 0.2$ & 5.55 & 5.40 & 5.37 & $5.44 \pm 1.8$ \\
\hline $\mathrm{C}_{28}$ & 1.31 & 1.28 & 1.29 & $1.29 \pm 1.2$ & 1.13 & 1.17 & 1.09 & $1.13 \pm 3.5$ \\
\hline $\mathrm{C}_{20}$ & 9.24 & 9.19 & 9.24 & $9.22 \pm 0.3$ & 9.01 & 9.06 & 8.98 & $9.02 \pm 0.4$ \\
\hline $\mathrm{C}_{30}$ & 9.77 & 9.75 & 9.86 & $9.79 \pm 0.6$ & 9.42 & 9.33 & 9.36 & $9.37 \pm 0.5$ \\
\hline $\mathrm{C}_{31}$ & 39.19 & 39.47 & 39.87 & $39.51 \pm 0.9$ & 40.50 & 39.55 & 40.92 & $40.32 \pm 1.7$ \\
\hline$c_{32}$ & 17.01 & 16.91 & 16.86 & $16.93 \pm 0.5$ & 16.87 & 16.48 & 16.95 & $16.77 \pm 1.5$ \\
\hline $\mathrm{C}_{33}$. & 15.41 & 15.13 & 14.84 & $15.13 \pm 1.9$ & 16.65 & 15.25 & 15.31 & $15.40 \pm 1.4$ \\
\hline $\mathrm{C}_{34}$ & 1.25 & 1.04 & 0.97 & $1.09 \pm 13.4$ & 0.72 & 0.88 & 0.73 & $0.78 \pm 11.5$ \\
\hline \multicolumn{9}{|c|}{ Leaf percentage+ } \\
\hline Total hydrocarbons & 0.188 & 0.185 & 0.183 & $0.185 \pm 0.6$ & 0.188 & 0.189 & 0.190 & $0.189 \pm 0.5$ \\
\hline Neophytadiene++ & 0.131 & 0.139 & 0.133 & $0.134 \pm 3.1$ & 0.136 & 0.144 & 0.144 & $0.141 \pm 3.3$ \\
\hline
\end{tabular}

- Based on total hydrocarbon area count; areas corrected for difference In detector response; methy!-branched Isomer assumed to respond identically with straight-chain isomer; average of two GC determinations on each replicate sample.

* Total $n-, i-$, and a-lsomors.

+ Based on dry welght.

++ Assumed to respond Identically with phytane.

capillary GC is about half of that for packed column GC. The use of an automatic sample injection assembly also allows the handling of a large number of samples. Consequently, both modifications have greatly facilitated and shortened the hydrocarbon analysis. This rapid method for leaf hydrocarbons will now be used to screen numerous tobacco variety samples to test our hypothesis that hydrocarbon distribution may be characteristic of a tobacco's genetic badkground.

\section{SUMMARY}

A rapid method for the analysis of aliphatic hydrocarbons and neophytadiene in cured tobacco was developed. Briefly, ground tobacco was extracted for $15 \mathrm{~min}$ with methylene chloride in a flask placed in an ultrasonic vibration bath. 3-Methyltricosane was added as the internal standard. The solution was filtered and the solvent removed. The sample was redissolved in hexane and chromatographed on a small silicic acid column. The hydrocarbon-neophytadiene fraction that eluted with hexane was reduced in volume and analyzed on a SE-54 wall-coated glass capillary column, which resolved and permitted quantitation of the normal, iso-methylbranched, and anteiso-methyl-branched hydrocarbons. The analytical data obtained by this method were equal to those obtained by the conventional Soxhlet extraction procedure. Based on experience in our laboratory, analysis time was reduced about fivefold and isomeric hydrocarbons were resolved by capillary gas chromatography.

\section{ZUSAMMENFASSUNG}

Zur Bestimmung von aliphatischen Kohlenwasserstoffen und Neophytadien in getrocknetem Tabak wurde ein Schnellverfahren entwickelt, das aus folgenden Analyseschritten besteht: Gemahlener Tabak wurde $15 \mathrm{~min}$ lang mit Dichlormethan in einem Ultraschallvibrationsbad unter Zugabe von 3-Methyltrikosan als innerem Standard extrahiert. Nach Filtrierung der Lösung und Entfernung des Lösungsmittels wurde das Probegut erneut in Hexan gelöst und chromatographisch auf einer kleinen Kieselsäure-Säule aufgetrennt. Die die Kohlenwasserstoffe und Neophytadien enthaltende Fraktion, die mit Hexan eluiert wurde, wurde eingedampft und gaschromatographisch unter Einsatz einer mit SE-54 beschichteten Glaskapillarsäule untersucht, wodurch die Auflösung und die quantitative Bestimmung von unverzweigten, iso-methylverzweigten und anteiso-methylverzweigten Kohlenwasserstoffen erreicht wurde. Mit diesem Verfahren wurden die gleichen Analysewerte erhalten wie mit der herkömmlichen Soxhlet-Extraktionsmethode. Die praktische Anwendung der Methode zeigte, daß bei diesem neuen Verfahren die Analysendauer auf ein Fünftel verkürzt werden kann, wozu noch der Vorteil einer differenzierteren Aussage durch die Auftrennung der isomeren Kohlenwasserstoffe mit Kapillargaschromatographie kommt.

\section{RESUME}

Une méthode rapide pour l'analyse des hydrocarbures aliphatiques et du néophytadiène dans le tabac séché a 
été mise au point. La méthode opère comme suit: Le tabac moulu est extrait avec du chlorure de méthylène pendant 15 minutes dans un flacon placé dans un bain à ultra-sons avec adjonction de 3-méthyltricosane comme référence interne. Après filtrage de la solution et évaporation du solvant, le résidu est redissous dans de I'hexane et chromatographié sur une petite colonne d'acide silicique. La fraction contenant les hydrocarbures et le néophytadiène, éluée avec l'hexane, est concentrée et chromatographiée sur une colonne capillaire de verre imprégnée de SE-54, résultant dans la séparation et la détermination quantitative des hydrocarbures normaux, iso-méthylés et anteiso-méthylés. Les résultats obtenus par cette méthode sont identiques à ceux obtenus par le procédé d'extraction conventionnel au Soxhlet. L'expérience des auteurs démontre, en outre, que la nouvelle méthode ne requiert qu'un cinquième du temps, sans compter l'avantage de la séparation des hydrocarbures isomères par la chromatographie sur colonne capillaire.

\section{REFERENCES}

1. Mold, J. D., R. K. Stevens, R. E. Means and J. M. Ruth: The paraffin hydrocarbons of tobacco / Normal, iso-, and anteiso-homologs; Biochem. 2 (1963) 605-610.

2. Chortyk, O. T., R. F. Severson and H. C. Higman: Chromatographic determination of hydrocarbon waxes in tobacco leaf and smoke; Beitr. Tabakforsch. 8 (1975) 204-210.

3. Jenkins, R. W., R. H. Newman, R. D. Carpenter and T.S. Osdene: Cigarette smoke formation studies, I. Distribution and mainstream products from added ${ }^{14} \mathrm{C}$-dotriacontane-16,17; Beitr. Tabakforsch. 5 (1970) 295-298.

4. Jenkins, R. W., R. H. Newman, M. D. Edmonds and T. S. Osdene: Cigarette smoke formation studies, III. The contribution of dotriacontane to the benzo(a)pyrene content of smoke; Beitr. Tabakforsch. 7 (1973) 154-157.

5. Severson, R. F., R. F. Arrendale, O. T. Chortyk and M. E. Snook: A method for determining the transfer of lipids from tobacco to smoke; Tob. Sci. XXII (1978) 130-133.
6. Ivanov, N., and I. Ognyanov; On resins in Bulgarian Oriental tobaccos; Proceedings of 4th International Tobacco Scientific Congress, 1966, Athens, Greece, pp. 779-785.

7. Davis, D. L.: Waxes and lipids in leaf and their relationship to smoking quality and aroma; Recent Advances in Tobacco Science 2 (1976) 80-111.

8. Ellington, J. J., P. F. Schlotzhauer and A. I. Schepartz: Quantitation of tobacco lipids; J. Chromatogr. Sci. 15 (1977) 295-300.

9. Severson, R .F., J. J. Ellington, R. F. Arrendale and M. E. Snook: Quantitative gas dhromatographic method for the analysis of aliphatic hydrocarbons, terpenes, fatty alcohols, fatty acids, and sterols in tobacco; J. Chromatogr. 160 (1978) 155-168.

10. Arrendale, R. F., L. B. Smith and L. B. Rogers: Comparison of dynamically coated SE-54, SP-2250 and Carbowax 20M wall-coated open tubular (WCOT) glass capillary columns, prepared after surface pretreatment with Superox TM-4 or with $\mathrm{BaCO}_{3}$; Journal of High Resolution Chromatography and Chromatography Communications (HRC \& CC) 3 (1980) 115-123.

11. Severson, R. F., R. F. Arrendale and O. T. Chortyk: Simple conversion of two standard gas diromatographs to all glass capillary systems; Journal of High Resolution Chromatography and Chromatography Communications (HRC \& CC) 3 (1980) 11-15.

12. Chang, S. Y., and C. Grunwald: Duvatrienediols in cuticular wax of Burley tobacco leaves; J. Lipid Res. 17 (1976) 7-11.

13. Severson, R. F., K. L. McDuffie, R, F. Arrendale, O. T. Chortyk, G. R. Gwynn and J. F. Chaplin: The comparison of cuticular themistry of normal and insect-resistant tobaccos; Proceedings of the 33rd Tobacco Chemists' Researdh Conference, Lexington, KY, October 29-31, 1979.

\section{Autbors' address:}

Tobacco and Health Laboratory, Agricultural Researd U.S. Department of Agriculture, P.O. Box 5677, Athens, Georgia, 30613, U.S.A. 